\title{
EXAMINING THE EFFECTS OF ENVIRONMENTAL COMPONENTS ON TOURISM DESTINATION COMPETITIVENESS: THE MODERATING IMPACT OF COMMUNITY SUPPORT
}

\author{
Chee-Hua, Chin ${ }^{1 *}$, May-Chiun, Lo², Vikneswaran Nair ${ }^{3}$ and Peter Songan ${ }^{4}$ \\ ${ }^{1.2}$ Faculty of Economics and Business, Universiti Malaysia Sarawak, \\ 94300 Kota Samarahan, Sarawak, Malaysia \\ ${ }^{3}$ School of Hospitality, Tourism \& Culinary Arts, Taylors University, \\ 47500 Subang Jaya, Selangor, Malaysia \\ ${ }^{4}$ Faculty of Cognitive Sciences and Human Development, \\ Universiti Malaysia Sarawak, 94300 Kota Samarahan, Sarawak, Malaysia \\ *Corresponding author: cch.febunimas@hotmail.my
}

Published online: 30 December 2016

To cite this article: Chin, C.H., Lo, M.C., Nair, V., and Songan, P. (2016). Examining the effects of environmental components on tourism destination competitiveness: The moderating impact of community support. Asian Academy of Management Journal, 21(Supp. 1), 75-104. http://dx.doi.org/10.21315/aamj2016.21.supp.1.4

To link to this article: http://dx.doi.org/10.21315/aamj2016.21.supp.1.4

\begin{abstract}
Contemporarily, tourism sector is a highly competitive environment, which forces tourism players to provide better visitor services in order to stay competitive. In rural tourism, a growing niche in the tourism market, multiple components of environmental constructs play a crucial role in contributing to the sustainability and competitiveness of rural tourism destinations. Hence, this study examines the impact of environment components on development of rural tourism destination competitiveness from a local community perspective. In addition, community support was adopted as moderator variable to examine the relationship among the constructs. 299 respondents comprising of residents of rural tourism in Sarawak, Malaysia took part voluntarily in this study. Data analysis was performed using SPSS Version 21.0 and Smart PLS 2.0 (M3) to assess the developed model, based on path modelling and then bootstrapping. Interestingly, the findings revealed that four of the environmental constructs have had a significant positive impact on destination competitiveness from local communities' perspective.
\end{abstract}

Keywords: environmental components, destination competitiveness, community support, local communities, rural tourism destination, Malaysia 


\section{INTRODUCTION}

Tourism makes a vital contribution of economic benefits to communities (Yu, Chancellor, \& Cole, 2011) as well as being a source of growth for a country's economy (Kalaiya \& Kumar, 2015). According to the World Travel and Tourism Council 2015's report, the economic contributions of travel and tourism industry accounted for about 2.4 trillion US dollar to the world GDP with approximately 105 million jobs opportunities created (WTTC, 2015). In the past decades, tourism has experienced tremendous growth, and visitors are increasingly seeking new places to relax and rest, such as natural tourism destinations (Lin \& Yeh, 2013). This interest has attracted increased attention in rural tourism from governments, non-governmental organisations (NGOs), and industry players because of its significant role in leading economy activity and increasing rural incomes (Egbali, Nosrat, \& Ali-pour, 2011; Zoto, Qirici, \& Polena, 2013).

Malaysia's tourism industry has ranked as the second most important industry after the manufacturing sector for the last twenty years (Tsonis, Cheuk, Ing, \& Razli, 2009), is listed as one of the National Key Economic Areas (NKEA) under the Tenth Malaysia Plan and ranked the ninth most visited country in the world (Lo, Songan, Mohamad, \& Yeo, 2013). Furthermore, the Malaysia Government Transformation Program attempted to address the needs of rural communities (PEMANDU, 2010) by creating various programmes, such as the homestay programme, to increase rural communities' million inbound tourists' arrivals. With such a large number of tourists, Malaysia's rural tourism has a significant impact on the country's economy and a contributor to the nation's GDP. A large proportion of tourists travel to destinations for relaxation, recreation and getting acquainted with cultural traditions (Egbali et al., 2011). Hence, rural tourism, if equipped with distinct and varied assets, can be a popular tourism destination. Thus, incentives such as accommodation and visitor centre facilities have been developed by Malaysian government for decades (Musa, 2000). Sarawak, rich with various natural heritage and cultural uniqueness bring additional advantages to develop its tourism industry (Er \& Simon, 2015). According to Sarawak Corridor of Renewable Energy (2012), Sarawak is targeting for 4 million tourists' arrival and will be generating employment opportunities up to approximately 30,000 people in the state by the year 2020 (as cited in Er \& Simon, 2015, p. 1). Realising the important of tourism industry for the growth of country's economy, hence it is imperative to enhance the tourism destination competitiveness and sustainability over time. 
While tourism is actively promoted by government and also tourism industry players, however, the promotion activities for rural destinations are less advanced (Papeli, Mohamad, \& Mehdi, 2007). Lane (2009) highlighted that for rural tourism destinations to achieve competitiveness, their unique characteristics, landscapes, and attractions must be fully leveraged, developed and promoted. Existing research on competitiveness in tourism development has recommended a broad range of perspectives that should be investigated (e.g., Mihalic, 2000; Dwyer \& Kim, 2003; Lee \& King, 2008; Kim, 2012). In fact, from the limited number of studies on competitive strategies, communities' perceptions, attitudes, behaviour and involvement in tourism planning (Yoon, 2002) have not been clearly addressed. Furthermore, local community support and access to the natural attractions are keys to success for rural tourism (Melo \& Farias, 2014). However, over-exploitation and over-development of tourism activities often reduce the natural resources and communities' quality of life. Further, development process often ignore communities' point of view which leads to dissatisfaction among the local residents. Hence, the concept of rural tourism development can be improved. While there are benefits from tourism activities for industry players and local communities (Knollenberg, 2011), extensive growth of tourism without properly plans and controls tend to destroy major tourism attractions (Sanjay, 2008). In fact, rural areas attract tourists based on their distinct culture, history, natural environment, beautiful landscape (Erokhin, Heijman, \& Ivolga, 2014; Trukhachev, 2015) and community (unique ethnicity) atmosphere. Hence, without careful management, visitors can destroy sensitive environmental attractions at a location, effectively, "tourism can kill tourism" (Glasson, Godfrey, \& Goodey, 1995).

Meanwhile, tourism destination competitiveness is getting much concern from various stakeholders particularly in the rural setting as it is defined as a very important factor for the success of a tourist destination (Cimbaljevic \& Bucic, 2015). Undeniably, environmental constructs in tourism development are essential element of destination competitiveness, but support from local community also plays an important role in ensuring sustainability of rural tourism development (Spencer \& Nsiah, 2013) and conservation of local resources (Tosun, 2006). If effectively combined, these elements ensure competitiveness of tourism destinations. Undeniable, tourism developments have not only protected the quality of life of residents living near tourism destinations, but also developed a more sustainable tourism industry (Harrill, 2004) for tourism development investors and stakeholders (Rahmani, Hajari, Karimian, \& Hajilo, 2013). Even though academicians have studied residents' attitudes toward rural tourism 
development, however, this area is constantly overlooked during the initial stages of tourism development (Banks, 2010), which can lead to dissatisfaction in local communities. The outcomes of resident dissatisfaction can be obvious; visitors are not welcomed by residents, which jeopardizes their positive holiday experience (Gursoy, Jurowski, \& Uysal, 2002), and eventually affects revisit intentions and word-of-mouth recommendations (Yu et al., 2011).

Overall, properly planning rural tourism is vital as it benefits tourism stakeholders, such as local communities and industry players, and also tourists who experience natural and cultural resources. Thus, this study attempts to examine the effect of environmental constructs (e.g., environmental conservation, tourism infrastructure, carrying capacity, \& quality of environment) toward the development of rural tourism destination competitiveness from the local communities perspective and community support adopted as a moderator variable in moderating the relationship among the constructs. The present study makes significant contributions to rural tourism knowledge by investigating rural tourism destination competitiveness from a local community perspective. In addition, this research is unaware of existing research that investigated the relationship between environmental constructs toward destination competitiveness with the moderating impact of community support in the Malaysia context, particularly Sarawak. Hence, this study contributes to the existing literature, and further extends existing knowledge.

\section{LITERATURE REVIEW}

\section{Rural Tourism}

Rural tourism refers to tourism activity that takes place in the countryside (Ratz \& Puczko, 1998) and tourism is known as one of the priority tools for rural planning in Malaysia (Liu, 2006). The broader definition of rural tourism, as defined by Gannon (1988), is a range of activities, services and amenities related to tourism, provided by rural people to attract tourists to their area in order to increase local income. This was later developed and defined as a multi-faced activity that takes place in an environment outside heavily urbanised areas, and is dominated by agricultural pursuits, forestry or natural areas (Beeton, 2006). Recently, rural tourism was also defined as a rural environment which includes natural, cultural, and human experiences for visitors to relax (Erdeji, Gagic, Jovicic, \& Medic, 2013). Tourism has contributed to communities' welfare (local communities), travellers' experience as well as a country's income (Peptenatu, Pintilii, Drăghici, $\&$ Stoian, 2009). With the decline of traditional agrarian industries, rural tourism has been actively suggested as an alternative solution to generate income for rural 
communities (Ruiz-Molina, Gil-Saura, \& Moliner-Velázquez, 2010; Moric, 2013). If successful, rural tourism is a unique and valuable industry to further develop, because it contributes to the creation of employment opportunities in the rural sector and helps increase the quality of life for local communities (Warren, 2013).

In addition, rural tourism's connection to the physical natural environment (Hall \& Boyd, 2005; Brouder, 2013), which is less congested and has more natural amenities for the purpose of relaxation (Mohamad, Lo, Songan \& Yeo, 2012), means these are the attributes that attract tourists in making choices for holiday destination. Development of major cultural and natural heritage attractions (e.g., handicrafts, cultural amenities) plays a pivotal role in enabling communities to increase their income (Rahmani et al., 2013). As highlighted by Cawley and Gillmor (2008), rural tourism development should be community based and markedly involving a wide range of community resources. Not surprisingly, community support has been postulated as one of the importance components in ensuring sustainability and successful operation of rural tourism destinations (Sheldon \& Abenoja, 2001; Gursoy et al., 2002; Jurowski \& Gursoy, 2004).

\section{Environmental Constructs}

The environment has emerged to be of most concern to the public, followed by social-cultural and economic issues in the tourism industry. Stemming from the awareness, the environment has become one of the main pillars for sustainable tourism development, particularly, rural tourism destination (Sedmak \& Mihalic, 2008; Fons, Fierro, \& Patino, 2011). The term environmental constructs has been defined as related components that refer to the physical environment, which includes natural or manmade components and in a broader sense, social and cultural environments (Mihalic, 2000). Scholars (Goulding, Horan, \& Tozzi, 2014; $\mathrm{Yu}, 2014)$ revealed the importance of environment components, such as natural resources and cultural attractions of a tourism destination, in developing a unique tourism product to attract visitors. In addition, natural resources have turned out to be the most important authenticity element in developing key competitiveness of a tourism destination (Sedmak \& Mihalic, 2008). In this connection, it is vital to conserve the environment as much as possible to ensure sustainability of tourism attractions as the number of visitors increase. Findings from Reimer and Walter (2013) postulated that preservation practices have to focus on manmade components as much as natural environmental components, as all these form part of the tourism product that attracts tourists and must also satisfy community by increasing quality of life. Hence, the multi-environmental constructs include environmental conservation, tourism infrastructure, carrying capacity, and quality of environment. 


\section{Environmental Conservation}

The term "conservation" defined as managing the resources of the environment (e.g., air, water, soil, mineral resources and living species) in order to achieve the highest sustainable quality of life (Jafari, 2000). Subsequently, the emerging of "ecotourism" had indicated a strong correlation with environmental conservation (Zhang \& Lei, 2012). Specifically, ecotourism involved the environmental protection activities for ecological sustainability. Apparently, the implementation of conservation activities depends much on the resident attitudes and involvement (Mbaiwa, 2008) due to the reason that rural tourism destination is their long stay homelands, without their support and cooperates, the environmental conservation practices would mostly fail (Sekhar, 2003). Scholars (e.g., Candrea, 2013; Reimer \& Walter, 2013) have noting that preserving and conserving the environment significantly ensuring the sustainability of local communities' income. Apparently, the success and failure of environmental conservation very much depends on resident attitudes (Ite, 1996; Weladji, Stein, \& Vedeld, 2003), particularly in rural tourism (Taylor, 2000; Mbaiwa, 2008). Because tourist developments are developed and operated over a long period of time, communities' lack of cooperation or support for environmental conservation reduces the degree of success in conserving the tourism destination (Sekhar, 2003). In this way, Reimer and Walter (2013) postulated that tourism environments should be critically conserved in order to mitigate the adverse impact of overcrowding and increase the sustainability of tourism destination (Candrea, 2013).

\section{Tourism Infrastructure}

Tourism infrastructure is defined as physical element that is created or made to cater visitors and further divided into two main groups, namely soft infrastructure (e.g., services) and hard infrastructure (e.g., transportation facilities, information and access facilities) (Inskeep, 1991; Wilde \& Cox, 2008). Past researchers (e.g., Hankinson, 2004; Aref \& Gill, 2009) have affirmed transportation infrastructure as the fundamental tourism resources to enhance tourism destination competitiveness. Tourism infrastructure is vital to a tourism destination, particularly for rural tourism destination as it is the basic amenities and infrastructure to support tourism activities and enable tourists to reach the tourism destination. Scholars (Kaul, 1985; Wilde \& Cox, 2008; Aref \& Gill, 2009) have postulated the important of transportation infrastructure in the success or failure of a tourism destination. The various types of transportation infrastructure, from air, on water, and on land are recognised as the important infrastructure to connect one point to another. The availability of good transportation system is important (Prideaux, 2000) to overcome the physical 
barrier to reach a tourism destination, particularly if the rural tourism destination is geographically dispersed, and reduces transportation costs.

\section{Carrying Capacity}

Carrying capacity is defined by World Tourism Organization (WTO) (1994) as the maximum number of people that may visit a tourist destination at the same time and without degrading the physical, economic, socio-cultural environment and the quality of visitors' satisfaction. Collectively, the increasing numbers of tourists visiting a tourism destination would lead to the degradation of part of the natural resources, and hence, in the future, tourists will not experience the same natural beauty and resources as before. From this, the carrying capacity of a particular destination can be seen to influence sustainability of a tourism destination and competitiveness in a long run. Indeed, several authors posited that there is a positive relationship between carrying capacity and sustainable tourism destination (Butler, 1997; Liu, 2003), and problems start to occur if carrying capacity practice are not managed properly (Swarbrooke, 2002; Manuel \& Miguel, 2008). This reduces sustainability and competitiveness of the tourism destination.

\section{Quality of Environment}

The quality of environment significantly influenced the competitiveness of a rural tourism destination, as tourists visit is to experience the quality of natural features and beautiful scenery (Kulcsar, 2009). Quality of environment can refers to the quality of natural and beautiful scenery, clean water, fresh air, and species diversity of the destination (Mihalic, 2000). Furthermore, a proper conserve environment would provide a higher quality of environment that satisfies tourists (Zhang \& Lei, 2012; Melo \& Farias, 2014). Moreover, the quality of environment is also significantly determining locals' quality of life (Hunziker, Felber, Gehring, Buchecker, Bauer \& Kienast, 2008). A number of researchers have affirmed the importance of environmental quality, like the local landscape and environmental scenery, is a feature of a successful tourism destination (Sedmak \& Mihalic, 2008; Mak, Cheung, \& Law, 2009; Fons et al., 2011; Zhang \& Lei, 2012). Achieving quality requires both tourists and local community to actively participate in improving the environment and not further decrease the environmental conditions. Numerous improvement strategies can be employed, such as the local community actively supporting environmental management and the development of strong ecological features, and tourists being involved in environmental protection while visiting a tourism destination. 


\section{Community Support}

Scholars Spencer and Nsiah (2013) defined community support as an integral part of the tourism product and hospitality to the extent that individual community members can affect visitors' satisfaction, expenditure levels, and propensity to visit again and recommend the destinations to others. Both community participation and community involvement were categorised as the sub-dimensions of community support. Community participation can also lead to active community involvement in successful tourism development (Tosun, 2006; Miranda, 2007). Collectively, both community participation and involvement play a significant role in community support for tourism development (Jurowski \& Gursoy, 2004). Furthermore, community support for visitor services (Yoon, Gursoy, \& Chen, 2000; Fallon \& Kriwoken, 2003) and community involvement for improved access facilities (Jurowski, 1994; Yoon, 1998) also significantly contribute to the success of the tourism industry. A number of researchers have revealed that community support is essential in ensuring sustainable development of rural tourism industry as well as rural economic development (Sharma \& Dyer, 2009; Scales, 2014a). A few studies have suggested that it is vital for a community to support rural tourism development as local residents keep control and ownership of the tourism product offerings (Lewis, 1998; Jones, 2005; Tosun, 2006). Hence, rural tourism has become a viable strategy to develop rural community and sustain their income. In this regard, Lee (2011) further posited that community satisfaction will lead to tourists being welcome and provide visitors with high-quality experiences of rural environment (Lepp, 2007).

\section{Destination Competitiveness}

Tourism destination competitiveness refers to the destination's ability to generate welfare and sustainability (Cavender-Bares, Heffernan, King, Polasky, Balvanera, \& Clark, 2013). Hence, destination competitiveness is achieved when its market share and financial returns are increasing (Vengesayi, 2003). In the past, tourism destination competitiveness has been discussed from various perspectives, such as an environmental perspective (Mihalic, 2000), economic perspective (Buhalis, 2000), and social cultural perspective (Jennifer, Strickland-Munro, Allison, \& Moore, 2010). However, the majority of discussions were based on environmental perspectives (Ritchie \& Crouch, 1993; Hassan, 2000; Dwyer, Mistilis, Forsyth, \& Rao, 2001; Gomezelj \& Mihalic, 2008) in which the environment component was taken as one of the four determinants of tourism competitiveness other than comparative advantage, industry structure and demand factors (Hocquette \& Chatellier, 2011; Battaglini, Bovolenta, Gusmeroli, Salvador, \& Sturaro, 2014). Past studies have highlighted the importance of environmental components 
towards the sustainability of the tourism industry (Chandralal, 2010; Miller, 2001), the development of destination competitiveness strategy (Kim, 2012), have documented the importance of environmental components (such as environmental conservation, environmental education, cultural attractions) towards development of destination competitiveness (Mihalic, 2000; Kotane, 2011; Chen, Chen, \& Okumus, 2013; Spencer \& Nsiah, 2013).

Among literature documenting the contribution to destination competitiveness of tourism core resources and attractors (Ritchie \& Crouch, 1993; Buhalis, 2000; Hassan, 2000; Wilde \& Cox, 2008), price competitiveness (Dwyer, Forsyth, \& Rao, 2000; Kim, 2012), and quality management (Go \& Govers, 2000), scholar Mihalic (2000) focused on a different aspect, environmental management. Together, Gomezelj and Mihalic (2008) proposed that it is necessary to conserve the nature of the environment and at the same time ensure the sustainability of the core resources (Scales, 2014b; Battaglini et al., 2014). Collectively, the models developed in this context highlight that effective and efficient strategy improves destination performance and achieves competitiveness. In short, destination competitiveness can be enhanced through various strategies, including destination management, sustainable development, and improved quality of service experience (Buhalis, 2000; Ritchie \& Crouch, 2000; Dwyer \& Kim, 2003).

\section{Hypotheses Development}

\section{Environmental Constructs and Destination Competitiveness}

Rural tourism activities take place in the countryside (Kulcsar, 2009) and the environment aspects are the main attraction to lure tourists (Lo, Ramayah, Songan, \& Nair, 2013). Tourists visit a rural tourism destination because the environment is free from pollution problems (e.g., no water and air pollution, no destruction and deforestation) and they can relax (Miller, 2006; Goodwin, 2008). In addition, Mihalic (2000) noted that for a rural tourism destination to achieve competitiveness, environmental conservation practices play a vital role in sustaining the competitiveness of a rural tourism destination (Diaz \& Rodriguez, 2008). Hence, for a rural tourism destination to stay competitive, the preservation of natural resources is important (Angelkova, Koteski, Jakovlev, \& Mitrevska, 2012). Tourism infrastructure refers to the availability of transport services and basic amenities in a tourism destination (Mo, Howard, \& Havitz, 1993). These infrastructure facilities make a significant contribution to the development of destination quality (Murphy, Pritchard, \& Smith, 2000) and tourism destination competitiveness (Tozser, 2010). Dwyer and Kim (2003) also postulated that tourism infrastructure is next most significant factor in determining destination 
competitiveness after environmental indicators (Khadaroo \& Seetanah, 2008). Furthermore, the improved tourism infrastructure has increased the accessibility for tourists to reach a particular tourism destination (Su \& Wall, 2009) and this would lead to the increase of destination competitiveness (Hsueh \& Yeh, 2014). Likewise, the efficiency of tourism infrastructure for a tourism destination is the fundamental attraction that brings tourists to the destination (Mazilu \& Stancioiu, 2009; Moric, 2013).

Carrying capacity refers to the maximum number of tourists that can visit a tourism destination without reducing the quality of the natural environment and tourists' satisfaction (Nghi, Lan, Thai, Mai \& Thanh, 2007). The issues of carrying capacity get intense attention as it jeopardizes tourists' satisfaction. Moreover, other scholars (e.g., Mathew, 2009; Dwyer, 2001; Mihalic, 2000) have affirmed carrying capacity as the significant pillar and a key driver to achieve competitiveness. When the number of tourists visiting a destination increases, the degree of relaxation afforded tourists decreases. Furthermore, from the communities' perspectives, the number of tourist arrivals must be control in order to ensure the quality of environmental conditions guaranteed during their visit. Environmental quality refers to the quality of the natural attractions (Mihalic, 2000), which are a significant determinant in attracting tourists to a destination. Empirical studies show that the quality of the environment plays a vital role in the development of tourism destination competitiveness, particularly for rural tourism (Gooroochurn \& Sugiyarto, 2005; Royo-Vela, 2009; Park \& Yoon, 2009). In a study by Moric (2013), the "wild beauty" image or quality of natural habitat increased attractiveness of eco-rural tourism destinations. Thus, a competitive rural tourism destination should possess not only beautiful landscapes but also be hassle-free environments to lure tourists (Cai \& Li, 2009; Pesonen, 2012). Based on the above discussion, the hypotheses developed as following:

H1: Environmental conservation is positively related to destination competitiveness.

H2: Tourism infrastructure is positively related to destination competitiveness.

H3: Carrying capacity is positively related to destination competitiveness.

H4: Quality of environment is positively related to destination competitiveness. 


\section{Community Support Moderates Environmental Constructs and Destination Competitiveness}

Understanding the importance of local community support toward the development of sustainable rural tourism destinations (Muganda, Sirima, \& Ezra, 2013; Chandralal, 2010) is vital in demonstrating environmental conservation practices and contributing to the development of tourism destination competitiveness (Sekhar, 2003; Manyara \& Jones, 2007; Zhang \& Lei, 2012). Even though some tourists may stay in a destination for a long time, few may contribute to conservation, hence, the community itself needs to be involved in conserving the environmental resources (Fernando \& Long, 2012). Past research (e.g., Stronza \& Gordillo, 2008; Lo et al., 2013) has demonstrated that local community involvement and support for environmental conservation of tourism destinations produces better outcomes than the inclusion of other stakeholders. The development of tourism infrastructure significantly contributes to the creation of tourism destination competitiveness (Hankinson, 2004; Aref \& Gill, 2009). Community involvement in preparing local transportation services to tourists is also important to ensure the rural tourism facilities achieve a satisfactory level (McIntosh, Goeldner, \& Ritchie, 1995) and it contributes to the economic benefits for local communities and success for the destinations (Deery, Jago, \& Fredline, 2012). Although there is substantial literature documenting the importance of community support towards tourism development (Jamal \& Stronza, 2009; Matarrita-Cascante, Brennan \& Luloff, 2010; Muganda et al., 2013), however, community support towards tourism infrastructure also crucially contributes to the development of rural tourism destination competitiveness by providing more access facilities for tourists to reach the destination.

The issues of carrying capacity in a rural tourism destination are increasingly concerns held by tourists because they do not want their visit affected by the maximum number of tourists at a tourism destination (Wilde \& Cox, 2008). Past studies (e.g., Saarinen, 2006; Okech, 2011) revealed that the sustainability of tourism is associated with the level of involvement and participation of communities in the tourism development process. Local communities' involvement in controlling the number of visitors is essential to ensure the number of visitors does not exceed the maximum limit and community lifestyles and tourist satisfaction remain unaffected (Huh \& Vogt, 2008; Nunkoo \& Ramkissoon, 2010). Quality of environment is another important source of rural tourism destination competitiveness as compared with other tourism destinations (Park \& Yoon, 2009). Tourists are attracted to the natural components of a tourism destination in order to relax and enjoy during the 
whole vacation. In order to achieve destination sustainability, communities play an important role in conserving and maintaining the quality of the environment. In fact community support in the form of being involved and participating in maintaining the quality of environment is a crucial link in the development of competitive and sustainable rural tourism destination. Based on the above discussion, the hypotheses developed as following:

H5: Community support moderates environmental conservation and destination competitiveness.

H6: Community support moderates tourism infrastructure and destination competitiveness.

H7: Community support moderates carrying capacity and destination competitiveness.

H8: Community support moderates quality of environment and destination competitiveness.

\section{METHODOLOGY}

\section{Sample Selection and Data Collection}

In present research, an exploratory approach through distribution of questionnaires was conducted. The population of this study consists of local communities from the three rural tourism destinations in Sarawak, namely Bario Kelabit Highland, Annah Rais Bidayuh Longhouse, and Bako National Park. Data were collected through questionnaires administered by face-to-face interview in the local communities of three rural tourism destinations in Sarawak, Malaysia. An adequate number of samples for research is between 30 to 500 (Sekaran \& Bougie, 2010; Sekaran, 2000). In the present study, the minimum sample size $(n=60)$ was calculated using the formula taken from Hair, Black, Babin, Anderson and Tatham (2010). [The Minimum sample size $=\mathrm{WnXn}$, where, $\mathrm{Wn}=$ Observation (Weight determined by the multi variate technique); $\mathrm{Xn}=$ Observed variable. So, $10 \times 6$ variables $=60$ respondents]. However, a total of 450 questionnaires were distributed to the local communities from three selected rural tourism destination, only 299 were returned and used for analysis. The large number of questionnaires given out was to ensure a sufficient number of returned questionnaires. The selection of these respondents was based on convenience sampling due to the fact that in rural tourism destination the availability of respondents are limited. 


\section{Measures and Analysis}

Collectively, the items used to measure environment components were mainly adapted from Perdue, Long, and Allen (1990), Mihalic (2000), Dwyer and Kim (2003), Gebhard, Meyer, and Roth (2007), and Chen et al. (2013). In addition, items adapted to measure destination competitiveness were from Crouch and Ritchie (1999), Hassan (2000), Mihalic (2000), and Dwyer and Kim (2003). Last but not least, items adapted to measure community support were mainly from Jurowski (1994), Yoon (1998), and Yoon, et al. (2000). Respondents were asked to respond to each statement using a seven-point Likert scale (ranging from $1=$ strongly disagree to 7 = strongly agree) for each statement. Maddox (1985) recommended the use of Likert type scale in tourism research to get a better validity (Ko \& Stewart, 2002). To assess the model developed SmartPLS 2.0 (M3) software was used to analyze the data collected with the Structural Equation Modeling-Partial Least Square (SEM-PLS) approach. This included path modeling and then bootstrapping (Gudergan, Ringle, Wende, and Will, 2008; Chin, 1998). A total of 500 re-samples were used to generate the standard error of the estimate and t-values. PLS was used in this study is because of its ability to give more accurate estimates of moderator effects by accounting for the error that attenuates the estimated relationships and improves the validation of theories (Chin, Marcolin, \& Newsted, 2003; Helm, Eggert, \& Garnefeld, 2010).

\section{FINDINGS}

\section{Assessment of the Measurement Model}

First, confirmatory factor analysis (CFA) was conducted to test the item reliability, convergent validity, and discriminant validity of the measurements scales. As shown in Table 1, all the items loading (showed in final iteration) exceeded the minimum cut off point of 0.50 (Gefen, Straub, \& Boudreau, 2000; Bagozzi, Yi \& Philipps, 1991), thus, the internal consistency was achieved. In terms of convergent validity, all the composite reliability (CR) values were above the minimum cut off point of 0.7 (Chin, 2010; Riquelme \& Rios, 2010) and the average variance extracted (AVE) values meet the minimum criteria of 0.50 (Fornell \& Larcker, 1981). For discriminant validity (see Table 2), the value of AVE will be square rooted and testify against the intercorrelations of the construct with other constructs in the research model (Chin, 2010) and all the values noted as greater than each of the constructs correlations (Chin, 2010; Fornell \& Bookstein, 1982). Hence, the measurement model was satisfactory and provided sufficient evidences in term of reliability, convergent validity, and discriminant validity. 
Chee-Hua, Chin et al.

Table 1

Results of Measurement Model

\begin{tabular}{|c|c|c|c|c|c|c|c|}
\hline \multirow{2}{*}{$\begin{array}{l}\text { Model } \\
\text { Construct }\end{array}$} & \multirow{2}{*}{$\begin{array}{l}\text { Measurement } \\
\text { Item }\end{array}$} & Loading & $\mathrm{CR}^{\mathrm{a}}$ & $\mathrm{AVE}^{\mathrm{b}}$ & Loading & $\mathrm{CR}^{\mathrm{a}}$ & $\mathrm{AVE}^{\mathrm{b}}$ \\
\hline & & \multicolumn{3}{|c|}{ First iteration } & \multicolumn{3}{|c|}{ Final iteration } \\
\hline \multirow{4}{*}{$\begin{array}{l}\text { Carrying } \\
\text { Capacity }\end{array}$} & Carry_Capac01 & 0.769 & \multirow[t]{4}{*}{0.678} & \multirow[t]{4}{*}{0.357} & 0.797 & \multirow[t]{4}{*}{0.725} & \multirow[t]{4}{*}{0.512} \\
\hline & Carry_Capac02 & 0.501 & & & 0.584 & & \\
\hline & Carry_Capac03 & 0.423 & & & Omitted & & \\
\hline & Carry_Capac04 & 0.637 & & & 0.663 & & \\
\hline \multirow{5}{*}{$\begin{array}{l}\text { Community } \\
\text { Support }\end{array}$} & Impro_AccF01 & 0.697 & \multirow[t]{5}{*}{0.847} & \multirow[t]{5}{*}{0.529} & 0.711 & \multirow[t]{5}{*}{0.849} & \multirow[t]{5}{*}{0.533} \\
\hline & Impro_AccF02 & 0.593 & & & 0.568 & & \\
\hline & Supp_ViServ01 & 0.785 & & & 0.777 & & \\
\hline & Supp_ViServ02 & 0.808 & & & 0.814 & & \\
\hline & Supp_ViServ03 & 0.734 & & & 0.757 & & \\
\hline \multirow{14}{*}{$\begin{array}{l}\text { Destination } \\
\text { Competitiveness }\end{array}$} & Dest_Marke01 & -0.038 & \multirow[t]{14}{*}{0.800} & \multirow[t]{14}{*}{0.301} & Omitted & \multirow[t]{14}{*}{0.888} & \multirow[t]{14}{*}{0.500} \\
\hline & Dest_Marke02 & 0.723 & & & 0.745 & & \\
\hline & Dest_Marke03 & 0.674 & & & 0.684 & & \\
\hline & Dest_Marke04 & 0.777 & & & 0.792 & & \\
\hline & Dest_Marke05 & 0.172 & & & Omitted & & \\
\hline & Qual_Servic01 & -0.103 & & & Omitted & & \\
\hline & Qual_Servic02 & 0.615 & & & 0.630 & & \\
\hline & Qual_Servic03 & 0.668 & & & 0.678 & & \\
\hline & Qual_Servic04 & 0.100 & & & Omitted & & \\
\hline & Sust_Manage01 & 0.048 & & & Omitted & & \\
\hline & Sust_Manage02 & 0.462 & & & Omitted & & \\
\hline & Sust_Manage03 & 0.713 & & & 0.708 & & \\
\hline & Sust_Manage04 & 0.736 & & & 0.715 & & \\
\hline & Sust_Manage05 & 0.704 & & & 0.689 & & \\
\hline \multirow{4}{*}{$\begin{array}{l}\text { Environmental } \\
\text { Conservation }\end{array}$} & Env_Conserv01 & 0.824 & \multirow[t]{4}{*}{0.873} & \multirow[t]{4}{*}{0.635} & 0.825 & \multirow[t]{4}{*}{0.873} & \multirow[t]{4}{*}{0.635} \\
\hline & Env_Conserv02 & 0.901 & & & 0.900 & & \\
\hline & Env_Conserv03 & 0.779 & & & 0.780 & & \\
\hline & Env_Conserv04 & 0.665 & & & 0.665 & & \\
\hline \multirow{4}{*}{$\begin{array}{l}\text { Quality of } \\
\text { Environment }\end{array}$} & Qual_Env01 & 0.714 & \multirow[t]{4}{*}{0.705} & 0.456 & 0.713 & 0.822 & 0.607 \\
\hline & Qual_Env02 & 0.859 & & & 0.858 & & \\
\hline & Qual_Env03 & 0.757 & & & 0.760 & & \\
\hline & Qual_Env04 & -0.049 & & & Omitted & & \\
\hline Tourism & Tou_Infras01 & 0.609 & 0.825 & 0.489 & 0.625 & 0.823 & 0.501 \\
\hline Infrastructure & Tou_Infras02 & 0.708 & & & 0.714 & & \\
\hline & Tou_Infras03 & 0.578 & & & 0.550 & & \\
\hline & Tou_Infras04 & 0.821 & & & 0.826 & & \\
\hline & Tou_Infras05 & 0.752 & & & 0.742 & & \\
\hline
\end{tabular}

Note:

${ }^{a}$ Composite Reliability $(\mathrm{CR})=($ square of the summation of the factor loadings $) /\{$ (square of the summation of the factor loadings $)+$ (square of the summation of the error variances $)\}$

${ }^{\mathrm{b}}$ Average Variance Extracted $(\mathrm{AVE})=($ summation of the square of the factor loadings $) /\{($ summation of the square of the factor loadings) + (summation of the error variances) $\}$

* Carry_Capac03, Dest_Marke01, Dest_Marke05, Qual_Servic01, Qual_Servic04, Sust_Manage01, Sust_Manage02, \& Qual_Env04 were deleted due to low loading. 


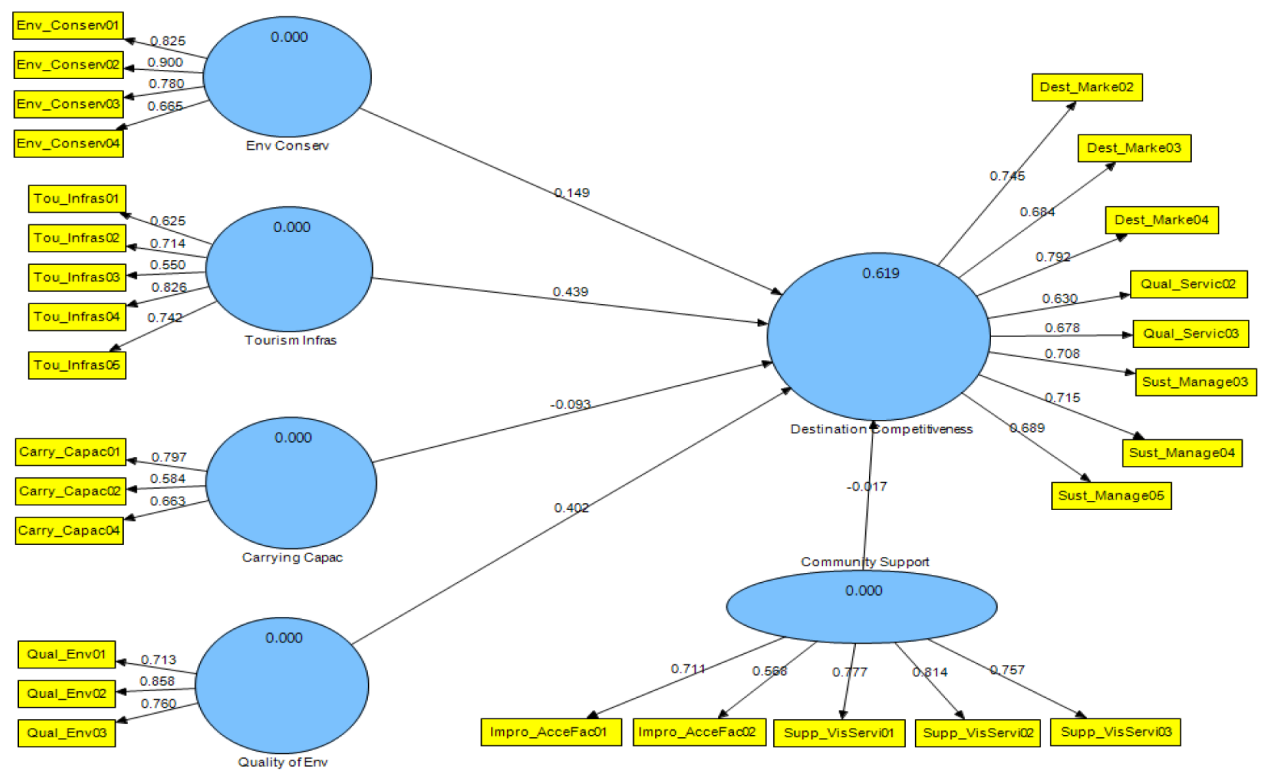

Figure 1. Results of the Path Analysis

Table 2

Discriminant Validity of Constructs

\begin{tabular}{lcccccc}
\hline & $\begin{array}{c}\text { Carrying } \\
\text { Capac }\end{array}$ & $\begin{array}{c}\text { Community } \\
\text { Support }\end{array}$ & $\begin{array}{c}\text { Destination } \\
\text { Competitiveness }\end{array}$ & $\begin{array}{c}\text { Env. } \\
\text { Conserv }\end{array}$ & $\begin{array}{c}\text { Quality } \\
\text { of Env }\end{array}$ & $\begin{array}{c}\text { Tourism } \\
\text { Infras }\end{array}$ \\
\hline $\begin{array}{l}\text { Carrying } \\
\text { Capacity }\end{array}$ & $\mathbf{0 . 7 1 6}$ & & & & & \\
$\begin{array}{l}\text { Community } \\
\text { Support }\end{array}$ & 0.095 & $\mathbf{0 . 7 3 0}$ & & & & \\
$\begin{array}{l}\text { Destination } \\
\text { Competitiveness }\end{array}$ & -0.135 & -0.083 & $\mathbf{0 . 7 0 7}$ & & & \\
$\begin{array}{l}\text { Environmental } \\
\text { Conservation }\end{array}$ & -0.123 & 0.001 & 0.404 & $\mathbf{0 . 7 9 7}$ & & \\
$\begin{array}{l}\text { Quality of } \\
\text { Environment }\end{array}$ & -0.070 & -0.174 & 0.328 & 0.290 & $\mathbf{0 . 7 7 9}$ & \\
$\begin{array}{l}\text { Tourism } \\
\text { Infrastructure }\end{array}$ & 0.015 & 0.030 & 0.452 & 0.378 & 0.394 & $\mathbf{0 . 7 0 8}$ \\
\hline
\end{tabular}

Note: Diagonals represent the square root of the average variance extracted (AVE) while the other entries represent the correlations. 


\section{Assessment of the Structural Model}

Next, Figure 2 and Table 3 present the results of the hypotheses testing. Interestingly, the statistical results showed that four of the direct hypotheses were supported. The results revealed that environmental conservation, tourism infrastructure, carrying capacity, and quality of environment were positive significantly related to destination competitiveness. Surprisingly, community support was found not moderates the relationship between environmental constructs and destination competitiveness. Hence, H1, H2, H3, and H4 were supported, whereas H5, H6, $\mathrm{H} 7$, and $\mathrm{H} 8$ were rejected.

Table 3

Path Coefficients and Hypothesis Testing

\begin{tabular}{|c|c|c|c|c|}
\hline Hypothesis & Relationship & Coefficient & t-value & Supported \\
\hline H1 & $\begin{array}{l}\text { Environmental conservation } \rightarrow \\
\text { Destination competitiveness }\end{array}$ & 0.149 & $4.492 * *$ & Yes \\
\hline $\mathrm{H} 2$ & $\begin{array}{l}\text { Tourism infrastructure } \rightarrow \text { Destination } \\
\text { competitiveness }\end{array}$ & 0.439 & $8.908^{* *}$ & Yes \\
\hline $\mathrm{H} 3$ & $\begin{array}{l}\text { Carrying capacity } \rightarrow \text { Destination } \\
\text { competitiveness }\end{array}$ & -0.093 & $2.805^{* *}$ & Yes \\
\hline $\mathrm{H} 4$ & $\begin{array}{l}\text { Quality of environment } \rightarrow \text { Destination } \\
\text { competitiveness }\end{array}$ & 0.402 & $7.641^{* *}$ & Yes \\
\hline H5 & $\begin{array}{l}\text { Community support moderates } \\
\text { environmental conservation and } \\
\text { destination competitiveness }\end{array}$ & -0.029 & 0.439 & No \\
\hline H6 & $\begin{array}{l}\text { Community support moderates } \\
\text { tourism infrastructure and destination } \\
\text { competitiveness }\end{array}$ & -0.128 & 1.015 & No \\
\hline $\mathrm{H} 7$ & $\begin{array}{l}\text { Community support moderates carrying } \\
\text { capacity and destination competitiveness }\end{array}$ & -0.168 & 1.138 & No \\
\hline $\mathrm{H} 8$ & $\begin{array}{l}\text { Community support moderates quality } \\
\text { of environment and destination } \\
\text { competitiveness }\end{array}$ & 0.024 & 0.522 & No \\
\hline
\end{tabular}

${ }^{*} \mathrm{p}<0.05,{ }^{* *} \mathrm{p}<0.01$ 


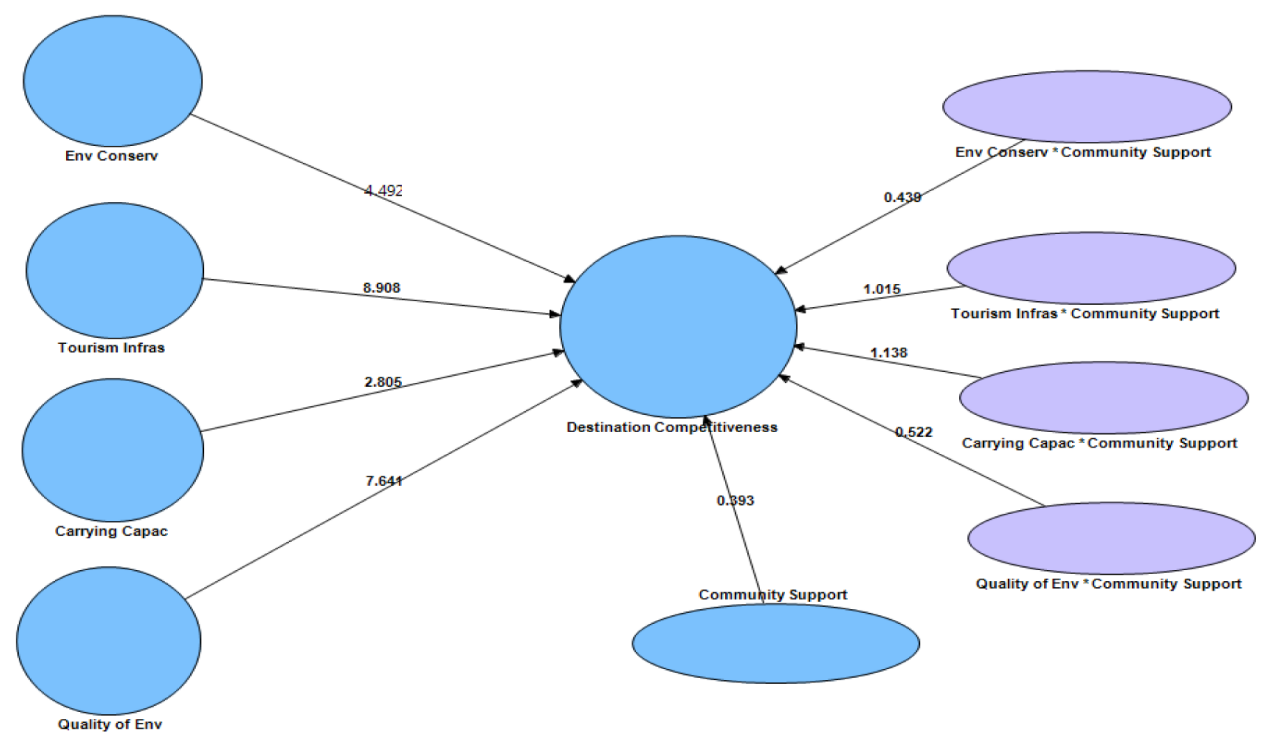

Figure 2. Research Model with $t$-value

\section{DISCUSSION}

The competitiveness of a rural tourism destination is very much depending on the availability of environmental and natural resources to lure tourists' attention to visit (Lokuhetty, Jayawardena, \& Mudadeniya, 2013; Erokhin et al., 2014). However, the increasing number of tourists would lead to the deterioration of environmental resources of the tourism destination if it is not properly managed. To this extent, environmental resources play a crucial role in determining competitiveness of a tourism destination. In a simple form, rural tourism destination must consist of both quality natural and man-made resources in order to maintain it comparative and competitive advantage as compare to others tourism destination (Angelkova et al., 2012). Furthermore, the local communities' perspective towards tourism development crucially determine the success and failure of a tourism destination (Muganda et al., 2013) as communities' dissatisfaction would lead to tourists not being welcomed.

The findings of this study revealed that environmental conservation had a significant impact on destination competitiveness $(\beta=0.149 ; t=4.492$; $p<0.01$ ), and thus H1 was supported. The findings of this study congruence to past studies (e.g., Diaz and Rodriguez, 2008; Zhang \& Lei, 2012) which revealed that environmental conservation is significantly influenced destination 
competitiveness. The conservation of flora and fauna is increasingly getting concern from various stakeholders (Lokuhetty et al., 2013) due to the fact that a better environmental conservation practices would leads to the sustainability of ecological and natural resources for a tourism destination. Communities believe that the quality of environmental resources (such as natural amenities, cultural and heritage resources, and tourism infrastructure) significantly determine tourists' intention to visit. Hence, it is vital to preserve and conserve the environmental resources in order to maintain their unique selling proposition (USP) and develop tourism destination competitiveness in a long run.

As expected, the empirical results showed that tourism infrastructure had a significant impact on destination competitiveness $(\beta=0.439 ; t=8.908 ; p<0.01)$, and thus hypothesis 2 was supported. In the study by Aref and Gill (2009) showed that the significant impact of transportation infrastructure in determining the success and failure of a tourism destination and later enhance the competitiveness of a tourism destination (Hsueh \& Yeh, 2014). On the other hand, a quality and improved tourism infrastructure has solved the issues of accessibility for tourists to reach a particular tourism destination (Su \& Wall, 2009) and this resources may become one of the fundamental attractors to attract tourists' visit (Moric, 2013; Zeinali \& Jafarpour, 2015). The findings of this hypothesis can be justifiable that the quality of tourism infrastructure have significantly affected tourists' intention to visit a rural tourism destination. The infrastructure at the touristic areas plays an important role in attracting tourists as safety issues have been one of the important agenda for tourists when deciding on places to visits.

As hypothesised, the findings showed that carrying capacity had a significant positive impact on destination competitiveness $(\beta=-0.093 ; t=2.805 ; p<0.01)$, and thus hypothesis 3 was supported. Carrying capacity refers to the maximum number of tourists visiting during a specific time frame which does not influence tourists' satisfaction levels (Nghi et al., 2007). Controlling the number of tourists visiting a destination is vital to overcome issues of overcrowding and sustaining the tourism destination (Manuel \& Miguel, 2008). As the motivation of tourists to visit a rural tourism destination is to enjoy and relax in the natural and cultural amenities (Faulkner \& Tideswell, 2005), and thus, uncontrolled visitor numbers may jeopardize tourists' experience and satisfaction (Yu et al., 2011). In particular, ecological carrying capacity referred in this hypothesis is about the maximum number of visitors visiting a particular rural tourism destination at a time. This is vital to provide the best environmental condition for tourists to enjoy and relax while maintaining and protecting the ecological resources for future generation. Hence, it is important to control the number of tourists visiting at a time in order to maintain the competitiveness of these rural tourism areas. 
On the other hand, the statistical results also indicated that quality of environment had a significant impact on destination competitiveness $(\beta=0.402 ; t=7.641 ; p<$ 0.01), and H4 was supported. For example, Zhang and Lei (2012) found a positive linkage between quality of environment and destination competitiveness and success of a tourism destination (Fons et al., 2011). Quality of environment is a strong determinant in development of destination competitiveness (Kayar \& Kozak, 2008) and significantly influences the competitiveness of a tourism destination to attract tourists (Williams \& Cary, 2002). The overall competitiveness of a tourism destination, particularly a rural tourism setting, is heavily dependent on the quality of environment (such as beautiful landscapes and hassle-free environments) to attract tourists. Hence, the availability of quality environmental resources would highly determine the competitiveness of a rural tourism destination. In addition, the quality of the environment is not merely to maintain the attraction level but it is also an important contributor to the local's quality of life while promising tourists' travel experience.

Noting that it is imperative to maintain the quality of tourism resources (such as natural resources, quality of environment and tourism infrastructure) as its significantly determine tourists' intention to visit a rural tourism destination (Lepp $\&$ Holland, 2006). Hence, it is vital for rural communities to preserve and practice various environmental conservation strategies in order to maintain their existence of "unique selling proposition" (Lo, Mohamad, Songan, \& Yeo, 2012) and this may lead to the development of tourism destination competitiveness over time. Overall, this study examines the relative importance of environmental constructs that contribute to destination competitiveness. The results of this research may lead to the application of the right marketing efforts that lead to long term sustainable practices for rural tourism development.

\section{CONCLUSION}

Overall, this study has investigated the importance of environmental constructs towards the development of rural tourism destination competitiveness from local communities' perspective. From the local communities' point of view, the results have revealed that environmental conservation, tourism infrastructure, carrying capacity, and quality of environment are the most important factors in contributing to the development of rural tourism destination competitiveness. It is believed that these findings are important to both researchers and practitioners with regards to rural tourism. Hence, this study provides a better understanding of communities' perception towards development of tourism destination competitiveness. Thus, the empirical evidence provided by this study offers actionable information to tourism 
planners and policy makers on the environmental constructs that have greatest influence on rural tourism destination success. Overall, the most important outcome is that collaborating with local communities to identify an effective strategy has the greatest impact on the success of sustainable rural tourism development. In future, researchers who are interested in this field can further test the relationships among these constructs in other tourism destination specifically rural tourism destination.

\section{ACKNOWLEDGEMENT}

The funding for this project was made possible through the research grant obtained from the Ministry of Higher Education, Malaysia under the Long Term Research Grant Scheme 2011 [LRGS grant no: JPT.S (BPKI)2000/09/01/015Jld.4(67)]

\section{REFERENCES}

Angelkova, T., Koteski, C., Jakovlev, Z., \& Mitrevska, E. (2012). Sustainability and competitiveness of tourism. Procedia - Social and Behavioral Sciences, 44, $221-$ 227. http://dx.doi.org/10.1016/j.sbspro.2012.05.023

Aref, F. \& Gill, S. S. (2009). Rural tourism development through rural cooperatives. Nature and Science, 7(10), 68-73.

Bagozzi, R. R., Yi, Y., \& Philipps, L. W. (1991). Assessing construct validity in organizational research. Administrative Science Quarterly, 36, 421-458. http:// dx.doi.org/10.2307/2393203

Banks, C. E. (2010). Disentangling the influence of community and place attachment on resident attitudes toward tourism development. A thesis submitted to the Graduate Faculty of North Carolina State University in partial fulfilment of the requirements for the degree of Master of Science.

Battaglini, L., Bovolenta, S., Gusmeroli, F., Salvador, S., \& Sturaro, E. (2014). Environmental sustainability of Alpine livestock farms. Italian Journal of Animas Science, 13, 431-443. http://dx.doi.org/10.4081/ijas.2014.3155

Beeton, S. (2006). Community development through tourism. Australia: Landlink Press.

Brouder, P. (2013). Tourism development in peripheral areas: Processes of local innovation and change in Northern Sweden (Doctoral dissertation). Ostersund: Mid Swedish University.

Buhalis, D. (2000). Marketing the Competitive Destination of the Future. Tourism Management, 21(1), 97-116. http://dx.doi.org/10.1016/S0261-5177(99)00095-3

Butler, R. V. (1997). The Concept of Carrying Capacity for Tourism Destinations: Dead or Merely Buried? In C. Cooper and S. Wanhill (Eds.), Tourism development: Environmental and community issues. Chichester: John Wiley \& Sons.

Cai, L. \& Li, M. (2009). Distance-segmented rural tourists. Journal of Travel \& Tourism Marketing, 26(8), 751-761. http://dx.doi.org/10.1080/10548400903356137 
Candrea, A. N. (2013). Ecotourism development in Romania - A possible contribution to the fulfillment of the real convergence criteria for euro adoption. Bulletin of the Rransilvania University of Brasov, 6(1), 90-96.

Cavender-Bares, J., Heffernan, J., King, E., Polasky, S., Balvanera, P., \& Clark, W. C. (2013). Sustainability and biodiversity. In S. A. Levin (Ed.), Encyclopedia of biodiversity Elsevier, Amsterdam, The Netherlands (pp. 71-84). http://dx.doi. org/10.1016/B978-0-12-384719-5.00390-7

Cawley, M. \& Gillmor, D. A. (2008). Integrated rural tourism: Concepts and practice. Annals of Tourism Research, 35(2), 316-337. http://dx.doi.org/10.1016/j. annals.2007.07.011

Chandralal, K. P. L. (2010). Impacts of tourism and community attitude towards tourism: A case study in Sri Lanka. South Asian Journal of Tourism and Heritage, 3(2), 41-49.

Chen, H. J., Chen, P. J., \& Okumus, F. (2013). The relationship between travel constraints and destination image: A case study of Brunei. Tourism Management, 35, 198208. http://dx.doi.org/10.1016/j.tourman.2012.07.004

Chin, W. W. (1998). The partial least squares approach to structural equation modeling. In G. A. Marcoulides (Ed.), Modern business research methods. Mahwah, NJ: Lawrence Erlbaum Associates.

Chin, W. W. (2010). How to write up and report PLS analyses. In V. Esposito Vinzi, W. W. Chin, J. Henseler, \& H. Wang (Eds.), Handbook of partial least squares: Concepts, methods and application (pp. 645-689). New York: Springer. http:// dx.doi.org/10.1007/978-3-540-32827-8_29

Chin, W. W., Marcolin, B. L., \& Newsted, P. R. (2003). A partial least squares latent variable modeling approach for measuring interaction effects: Results from a monte carlo simulation study and electronic mail emotion/ adoption study. Information System Research, 14(2), 189-217.

Cimbaljevic, M. \& Bucic, A. (2015). Competitiveness of a Travel Destination - A Case Study of Montenegro in Relation to Relevant Models of Competitiveness. Proceedings of the International Student Conference in Tourism Research ISCONTOUR 2015 Tourism Research Perspectives, 271-284.

Crouch, G. I. \& Ritchie, J. R. B. (1999). Tourism, competitiveness, and societal prosperity. Journal of Business Research, 44, 137-152. http://dx.doi.org/10.1016/S01482963(97)00196-3

Deery, M., Jago, B.L., \& Fredline, L. (2012) Rethinking social impacts of tourism research: A new research agenda. Tourism Management, 33, 64-73. http://dx.doi. org/10.1016/j.tourman.2011.01.026

Diaz, M. R. \& Rodriguez, T. F. E. (2008). A model of strategic evaluation of a tourism destination based on internal and relational capabilities. Journal of Travel Research, 46, 368-380. http://dx.doi.org/10.1177/0047287507308324

Dwyer, L. (2001). Destination Competitiveness: Determinants and Indicators (Unpublished Report).

Dwyer, L., Forsyth, P., \& Rao, P. (2000). The price competitiveness of travel and tourism: a comparison of 19 destinations. Tourism Management, 21(1), 9-22. 
Dwyer, L., \& Kim, C. (2003). Destination competitiveness: Determinants and indicators. Current Issues in Tourism, 6(5), 369-414.

Dwyer, L., Mistilis, N., Forsyth, P., \& Rao, P. (2001). International price competitiveness of Australia's MICE industry. The International Journal of Tourism Research, $3(2), 123-139$.

Egbali, N., Nosrat, A. B., \& Ali-pour, S. K. S. (2011). Effects of positive and negative rural tourism (case study: Rural Semnan Province). Journal of Geography and Regional Planning, 4(2), 63-76.

Er, A. C., \& Simon, S. (2015). Marketing Mix of Ecotourism Product in Kuching, Sarawak, Malaysia. Mediterranean Journal of Social Sciences, 6(4), 39-47.

Erdeji, I., Gagic, S., Jovicic, A., \& Medic, S. (2013). Development of rural tourism in Serbia. Journal of Settlements and Spatial Planning, 20(Special Issue), 309-315.

Erokhin, V., Heijman, W., \& Ivolga, A. (2014). Sustainable rural development in Russia through diversification: The case of the Stavropol Region. Visegr. Journal Bioecon. Sustainable Development, 1, 20-25.

Fallon, L. D., \& Kriwoken, L. K. (2003). Community involvement in tourism infrastructure: the case of the Strahan Visitor Centre, Tasmania. Tourism Management, 24, 289308.

Faulkner, B., \& Tideswell, C. (2005). Rejuvenating a maturing tourist destination: The case study.

Fernando, I. N., \& Long W. (2012). New conceptual model on cluster competitiveness: A new paradigm for tourism? International Journal of Business and Management, 7(9), 75-84.

Fons, M. V. S., Fierro, J. A. M., \& Patino, M. G. Y. (2011). Rural tourism: A sustainable alternative. Applied Energy, 88, 551-557.

Fornell, C., \& Bookstein, F. L. (1982). Two structural equation model: LISREL and PLS applied to consumer exit-voice theory. Journal of Marketing Research, 19, 440452.

Fornell, C. \& Larcker, D. F. (1981). Evaluating Structural Equation Models with Unobservable Variables and Measurement Error. Journal of Marketing Research, $18,39-50$.

Gannon (1988). In Kloeze, J. W. (1994). The benefit of rural tourism, the role of the state, and the aspects of the training and co-operation. Formal Speech held at the Central and East European Federation for the Promotion of the Green-Soft Rural Tourism Conference "Rural Tourism Development in Bulgaria and in the Balkan Countries.

Gebhard, K., Meyer, M., \& Roth, S. (2007). Criteria for sustainable tourism for the three Biosphere Reserves. Ecological Tourism in Europe and UNESCO MaB.

Gefen D., Straub, D. W., \& Boudreau, M. C. (2000). Structural Equation Modeling and Regression: Guidelines for Research Practice. Communications of the Association for Information Systems, 4(7), 1-70.

Glasson, J., Godfrey, K., \& Goodey, B. (1995). Toward Visitor Impact Management. London: Avebury. 
Go, F. M., \& Govers, R. (2000). Integrated quality management for tourist destinations: A European perspective on achieving competitiveness. Tourism Management, 21, 79-88.

Gomezelj, D. O., \& Mihalic, T. (2008). Destination competitiveness - Applying different models, the case of Slovenia. Tourism Management, 29, 294-307.

Goodwin, J. J. D. (2008). Sustainable tourism development in the Caribbean Island NationStates. Michigan Journal of Public Affairs, 5, 1-16.

Gooroochurn, N., \& Sugiyarto, G. (2005). Competitiveness indicators in the travel tourism industry. Tourism Economics, 11(1), 25-43.

Goulding, R., Horan, E., \& Tozzi, L. (2014). The importance of sustainable tourism in reversing the trend in the economic downturn and population decline of rural communities. Revista de Turismo y Patrimonio Cultural, 12(3), 549-563.

Gudergan, S. P., Ringle, C. M., Wende, S., \& Will, A. (2008). Confirmatory tetrad analysis in PLS path modeling. Journal of Business Research, 1-12.

Gursoy, D., Jurowski, C., \& Uysal, M. (2002). Resident attitudes - A structural modeling Approach. Annals of Tourism Research, 29(1), 79-105.

Hair, J. F., Black, W. C., Babin, B. J., Anderson, R. E., \& Tatham, R. L. (2010). Multivariate Data Analysis (6th ed.). Upper Saddle River: NJ: Prentice Hall.

Hall, C. M., \& Boyd, S. (2005). Nature-based Tourism in peripheral areas: Development or disaster?. Clevedon, UK: Channel View.

Hankinson, G. (2004). The brand images of tourism destinations: a study of the saliency of organic images. Journal of Product and Brand Management, 13(1), 6-14.

Harrill, R. (2004). Residents' attitudes toward tourism development: A literature review with implication for tourism planning. Journal of Planning Literature, 18(3), 251-66.

Hassan, S. S. (2000). Determinants of market competitiveness in an environmentally sustainable tourism industry. Journal of Travel Research, 38(3), 239-245.

Helm, S., Eggert, A., \& Garnefeld, I. (2010). Modeling the impact of corporate reputation on customer satisfaction and loyalty using partial least squares. In V. Esposito Vinzi, W. W. Chin, J. Henseler, \& H. Wang (Eds.), Handbook of partial least squares: Concepts, methods and applications (pp. 515-534). Heidelberg, Germany: Springer.

Hocquette, J. F., \& Chatellier, V. (2011). Prospects for the European beef sector over the next 30 years. Retrieved from http://www.animalfrontiers. org/content/1/2/20. full.pdf + ht $\mathrm{ml}$

Hsueh, Y. H., \& Yeh, H. M. (2014). Mapping spatial relationships among travel nodes for tourism development. International Journal of Current Research and Academic Review, 2(2), 199-211.

Huh, C., \& Vogt, C. A. (2008). Changes in residents' attitudes toward tourism over time: A cohort analytical approach. Journal of Travel Research, 46(4), 446-455.

Hunziker, M., Felber, P., Gehring, K., Buchecker, M., Bauer, N., \& Kienast, F. (2008). Evaluation of landscape change by different social groups. Mountain Research and Development, 28(2), 140-147.

Inskeep, E. (1991). Tourism planning: An integrated and sustainable development approach. New York: Van Nostrand Reinhold. 
Ite, U. E. (1996). Community perception of the cross river national park. Nigeria Environmental Conservation, 23(4), 351-357.

Jafari, J. (2000). Encyclopedia of tourism. London: Routledge.

Jamal, T., \& Stronza, A. (2009). Collaboration theory and tourism practice in protected areas: Stakeholders, structuring and sustainability. Journal of Sustainable Tourism, 17, 169-189.

Jennifer, K., Strickland-Munro, J. K., Allison, H. E., \& Moore, S. A. (2010). Using resilience concepts to investigate the impacts of protected area tourism on communities. Annals of Tourism Research, 37(2), 499-519.

Jones, S. (2005). Community-based ecotourism: The significance of social capital. Annals of Tourism Research, 32(2), 303-324.

Jurowski, C. (1994). The Interplay of elements Affecting Host Community Resident Attitudes toward Tourism: A Path Analytic Approach (Doctoral dissertation). Virginia Polytechnic Institute and State University.

Jurowski, C., \& Gursoy, D. (2004). Distance effects on residents' attitudes toward tourism. Annals of Tourism Research, 31(2), 296-312.

Kalaiya, A. B., \& Kumar, A. (2015). Tourism as a development tool: A study on role of tourism in economic development, employment generation and poverty reduction: Special focus on Kachchh. International Journal of Advance Research in Computer Science and Management Studies, 3(7), 189-197.

Kaul, R. N. (1985). Dynamics of tourism: A trilogy, Vol. 111. New Delhi: Transportation and Marketing.

Kayar, C. H., \& Kozak, N. (2008). Measuring destination competitiveness: An application of Travel and Tourism Competitiveness Index. The $4^{\text {th }}$ World Conference for Graduate Research in Tourism, Hospitality and Leisure.

Khadaroo, J., \& Seetanah, B. (2008). The role of transport infrastructure in international tourism development: A gravity model approach. Tourism Management, 29, 831840.

Kim, N. (2012). Tourism destination competitiveness, globalization, and strategic development from a development economics perspective. Dissertation submitted in partial fulfillment of the requirements for the degree of Doctor of Philosophy in Recreation, Sport and Tourism in the Graduate College of the University of Illinois at Urbana-Champaign.

Knollenberg, W. (2011). Stakeholders' attitudes towards sustainable tourism development in coastal communities. A dissertation presented to the Faculty in Sustainable Tourism, the Graduate School, East Carolina University in partial fulfillment of the requirements for the Degree of Master Science in Sustainable Tourism.

Ko, D. W., \& Stewart, W. P. (2002). A structural equation model of resident's attitudes for tourism development. Tourism Management, 23(5), 521-530.

Kotane, I. (2011). Culture as an element of sustainable development and urban attraction capacity. Management Theory and Studies for Rural Business and Infrastructure Development, 2(26).

Kulcsar, N. (2009). Rural tourism in Hungary: The key of competitiveness. Proceedings of FIKUSZ '09 Symposium for Young Researchers, 121-127. 
Lane, B. (2009). Rural tourism: An Overview. In M. Robinson, \& T. Jamal (Eds), The SAGE handbook of tourism studies (pp. 354-370). London: Sage Publications.

Lee, T. H. (2011). How recreation involvement, place attachment and conservation commitment affect environmentally responsible behavior. Journal of Sustainable Tourism, 19(7), 895-915.

Lee, C. F., \& King, B. (2008). Assessing destination competitiveness: An application to the hot springs tourism sector. International Journal of Tourism Research, 10(4), 341-352. http://dx.doi.org/10.1002/jtr.661

Lepp, A. (2007). Residents' attitudes towards tourism in Bigodi village, Uganda. Tourism Management, 28, 876-885. http://dx.doi.org/10.1016/j.tourman.2006.03.004

Lepp, A., \& Holland, S. (2006). A comparison of attitudes toward state-led conservation and community-based conservation in the village of Bigodi, Uganda. Society \& Natural Resources, 19(7), 609-623. http://dx.doi.org/10.1080/08941920600742377

Lewis, J. (1998). A rural tourism development model. Tourism Analysis, 2, 91-105.

Lin, L. Z., \& Yeh, H. R. (2013). Analysis of tour values to develop enablers using an interpretive hierarchy-based model in Taiwan. Tourism Management, 34, 133144. http://dx.doi.org/10.1016/j.tourman.2012.04.004

Liu, Z. (2003). Sustainable tourism development: a critique. Journal of Sustainable Tourism, 11, 459-475. http://dx.doi.org/10.1080/09669580308667216

Liu, A. (2006). Tourism in rural areas: Kedah, Malaysia. Tourism Management, 27, 878889. http://dx.doi.org/10.1016/j.tourman.2005.05.007

Lokuhetty, A., Jayawardena, C., \& Mudadeniya, D. (2013). Developing a shared vision for tourism in post- ward Sri Lanka. Worldwide Hospitality and Tourism Themes, 5(5), 486-494. http://dx.doi.org/10.1108/WHATT-05-2013-0030

Lo, M. C., Mohamad, A. A., Songan, P., \& Yeo, A. W. (2012). Positioning rural tourism: perspectives from the local communities. International Journal of Trade, Economics, and Finance, 3(1), 59-65. http://dx.doi.org/10.7763/IJTEF.2012. V3.173

Lo, M. C., Ramayah, T., Songan, P., \& Nair, V. (2013). Attitude of communities toward rural tourism development. Life Science Journal, 10(10s), 311-322.

Lo, M. C., Songan, P., Mohamad, A. A., \& Yeo, A. W. (2013). Rural tourism and destination image: Community perception in tourism planning. The Macrotheme Review, 2(1), 102-118.

Maddox, R. N. (1985). Measuring satisfaction with tourism. Journal of Travel Research, 23(3), 2-5. http://dx.doi.org/10.1177/004728758502300301

Mak, W., Cheung, R., \& Law, L. (2009). Sense of community in Hong Kong: relations with community-level characteristics and residents' well-being. American Journal of Community Psychology, 44(1), 80-92. http://dx.doi.org/10.1007/s10464-0099242-Z

Manuel, J. L-B., \& Miguel, L. L-B. (2008). Measuring social carrying capacity: An exploratory study. TOURISMOS: An International Multidisciplinary Journal of Tourism, 3(1), 116-134.

Manyara, G., \& Jones, E. (2007). Community-based tourism enterprises development in Kenya: An exploration of their potential as avenues of poverty reduction. Journal of Sustainable Tourism, 15(6), 628-644. http://dx.doi.org/10.2167/jost723.0 
Matarrita-Cascante, D., Brennan, M. A., \& Luloff, A. E. (2010). Community agency and sustainable tourism development: The case of La Fortuna, Costa Rica. Journal of Sustainable Tourism, 18,735-756.http://dx.doi.org/10.1080/09669581003653526

Mathew, V. (2009). Sustainable tourism: A case of destination competitiveness in South Asia. South Asian Journal of Tourism and Heritage, 2(1), 83-89.

Mazilu, M., \& Stancioiu, F. (2009). Tourist destination competitiveness: Between desirable and imperative. Geography Series, 12, 176-188.

Mbaiwa, J. E. (2008). Tourism development, rural livelihoods, and conservation in the Okavango Delta, Botswana. A Dissertation submitted to the Office of Graduate Studies of Texas A\&M University in partial fulfillment of the requirements for the degree of Doctor of Philosophy.

McIntosh, R. W., Goeldner, C. R., \& Ritchie, J. R. B. (1995). Tourism: Principles, practices, and philosophies $\left(7^{\text {th }}\right.$ ed.). New York, NY: John Wiley \& Sons.

Melo, F. V. S., \& Farias, S. A. D. (2014). Sustainability as an identity factor of tourist destinations at websites: Does the consumer care? Brazilian Business Review, 11(2), 135-158. http://dx.doi.org/10.15728/bbr.2014.11.2.6

Mihalic, T. (2000). Environmental management of a tourist destination: A factor of tourism competitiveness. Tourism Management, 21, 65-78. http://dx.doi.org/10.1016/ S0261-5177(99)00096-5

Miller, G. (2001). The development of indicators for sustainable tourism: Results of a Delphi survey of tourism researchers. Tourism Management, 22, 351-362. http:// dx.doi.org/10.1016/S0261-5177(00)00067-4

Miller, M. A. L. (2006). Paradise Sold, Paradise Lost: Jamaica's Environment and culture in the tourism marketplace. In Baver and Lynch, 35-43.

Miranda, E. M. (2007). Gang injunctions and community participation. University of Southern California.

Mo, C., Howard, D. R., \& Havitz, M. E. (1993). Testing an international tourist role typology. Annals of Tourism Research, 20, 319-335. http://dx.doi.org/10.1016/01607383(93)90058-B

Mohamad, A. A., Lo, M. C., Songan, P., \& Yeo, A. W. (2012). Dimensionality of communities' belief attitude toward rural tourism development. British Journal of Arts and Social Sciences, 6(2), 245-254.

Moric, I. (2013). Clusters as a factor of rural tourism competitiveness: Montenegro experiences. Business Systems Research, 4(2), 94-107. http://dx.doi.org/10.2478/ bsrj-2013-0015

Muganda, M., Sirima, A., \& Ezra, P. M. (2013). The role of local communities in tourism development: Grassroots perspectives from Tanzania. Journal of Human Ecological, 41(1), 53-66.

Murphy, P., Pritchard, M., \& Smith, B. (2000). The destination product and its impact on traveller perceptions. Tourism Management, 21, 43-52. http://dx.doi.org/10.1016/ S0261-5177(99)00080-1

Musa, G. (2000). Tourism in Malaysia. In C. M. Hall, \& S. Page (Eds.), Tourism in South and South-East Asia: Issues and cases (pp. 144-156). Oxford, England: Butterworth Heinemann. 
Nghi, T., Lan, N. T., Thai, N. D., Mai, D., \& Thanh, D. X. (2007). Tourism carrying capacity assessment for Phong Nhake Bang and Dong Hoi, Quang Binh Province. VNU Journal of Science, Earth Sciences, 23, 80-87.

Nunkoo, R., \& Ramkissoon, H. (2010). Modelling community support for a proposed integrated resort project. Journal of Sustainable Tourism, 18(2), 257-277.

Okech, R. N. (2011). Ecotourism development and challenges: A Kenyan experience. Tourism Anal., 16(1), 19-29. http://dx.doi.org/10.3727/108354211X12988225 899967

Papeli, Y., Mohamad, H., \& Mehdi, S. (2007). Tourism (nature and concepts). Samt Publication.

Park, D. B., \& Yoon, Y. S. (2009). Segmentation by motivation in rural tourism: A Korean case study. Tourism Management, 30, 99-108. http://dx.doi.org/10.1016/j. tourman.2008.03.011

PEMANDU (2010). Performance Management and Delivery Unit. Chapter 1: New Economic Model of Malaysia. Retrieved February 2, 2011 from http://etp.pemandu.gov.my/download_center-@-download_center.aspx.

Peptenatu, D., Pintilii, R. D., Drăghici, C. C., \& Stoian, D. (2009). Territorial disparities concerning the distribution of the tourist services quality in Romani. Geography Journal of Tourism and Geosites, 2(4), 105-117.

Perdue, R. R., Long, P. T., \& Allen, L. (1990). Resident support for tourism development. Annals of Tourism Research, 17, 586-599. http://dx.doi.org/10.1016/01607383(90)90029-Q

Pesonen, J. A. (2012). Segmentation of rural tourists: Combining push and pull motivations. Tourism and Hospitality Management, 18(1), 69-82.

Prideaux, B. (2000). The role of the transport system in destination development. Tourism Management, 21, 53-63. http://dx.doi.org/10.1016/S0261-5177(99)00079-5

Rahmani, S. M., Hajari, B., Karimian, T., \& Hajilo, M. (2013). Rural tourism development strategies using SWOT analysis: Case study. Life Science Journal, 10(4s), 395403.

Ratz, T., \& Puczko, L. (1998). Rural tourism management: Sustainable options. International Conference, September, SAC, Auchincruive, Scotland-Part 1.

Reimer, J. K., \& Walter, P. (2013). How do you know it when you see it? Community-based ecotourism in the Cardamom Mountains of Southwestern Cambodia. Tourism Management, 34, 122-132. http://dx.doi.org/10.1016/j.tourman.2012.04.002

Riquelme, H. E., \& Rios, R. E. (2010). The moderating effect of gender in the adoption of mobile banking. International Journal of Bank Marketing, 28(5), 328-341. http://dx.doi.org/10.1108/02652321011064872

Ritchie, B. J. R., \& Crouch, G. I. (1993). Competitiveness in international tourism - A framework for understanding and analysis. Reports on 43 $3^{\text {rd }}$ Congress, 35, 23-71.

Ritchie, J. R. B., \& Crouch, G. I. (2000). The competitive destination, a sustainable perspective. Tourism Management, 21(1), 1-7. 
Royo-Vela, M. (2009). Rural-cultural excursion conceptualization: A local tourism marketing management model based on tourist destination image measurement. Tourism Management, 30(3), 419-428. http://dx.doi.org/10.1016/j.tourman.2008. 07.013

Ruiz-Molina, M. E, Gil-Saura, I., \& Moliner-Velázquez, B. (2010). The role of information technology in relationships between travel agencies and their suppliers, Journal of Hospitality and Tourism Technology, 1(2), 144-162. http://dx.doi. org/10.1108/17579881011065047

Saarinen, J. (2006). Traditions of sustainability in tourism studies. Annals of Tourism Research, 33(4), 1121-1140. http://dx.doi.org/10.1016/j.annals.2006.06.007

Sanjay, K. (2008). Tourism-induced rural energy consumption in the annapurna region of Nepal. Tourism Management, 29, 89-100.

Sarawak Corridor of Renewable Energy. (2012). Economic Corridors: Your Gateway to Investing in Malaysia. Retrieved December 29, 2015 from myCorridor: http:// www.mycorridor.malaysia.gov.my/IC/SCORE/Pages/default.aspx

Scales, I. R. (2014a). The future of conservation and development in Madagascar: time for a new paradigm? Madagascar Conservation \& Development, 9(1), 5-12.

Scales, I. R. (2014b). The future of biodiversity conservation and environmental management in Madagascar: lessons from the past and challenges ahead. In I. R. Scales (Ed.), Conservation and environmental management in Madagascar (pp. 342-360). London and New York: Routledge.

Sedmak, G., \& Mihalic, T. (2008). Authenticity in mature seaside resorts. Ann. Tourism Res., 35(4), 1007-1031. http://dx.doi.org/10.1016/j.annals.2008.07.004

Sekaran, U. (2000). Research methods for business: A skill building approach (3rd ed.). New York: John Wiley \& Sons, Inc.

Sekaran, U., \& Bougie, R. (2010). Research Methods for Business: A Skill Building Approach (5th ed.). United Kingdom: John Wiley and Sons Ltd.

Sekhar, N. U. (2003). Local people's attitudes towards conservation and wildlife tourism around Sariska Reserve, India. Journal of Environmental Management, 69, 339347. http://dx.doi.org/10.1016/j.jenvman.2003.09.002

Sharma, B., \& Dyer, P. (2009). Residents' involvement in tourism and their perceptions of tourism impacts. Benchmarking: An International Journal, 16(3), 351-371.

Sheldon, P., \& Abenoja, T. (2001). Resident attitudes in a mature destination: The case of Waikiki. Tourism Management, 22, 435-443. http://dx.doi.org/10.1016/S02615177(01)00009-7

Spencer, D. M., \& Nsiah, C. (2013). The economic consequences of community support for tourism: A case study of a heritage fish hatchery. Tourism Management, 34, 221-230. http://dx.doi.org/10.1016/j.tourman.2012.04.003

Stronza, A., \& Gordillo, J. (2008). Community views of ecotourism. Annals of Tourism Research, 35(2), 448-468. http://dx.doi.org/10.1016/j.annals.2008.01.002

$\mathrm{Su}$, M. M., \& Wall, G. (2009). The Qing-Tibet railway and Tibetan tourism: Travelers perspectives. Tourism Management, 30, 650-657. http://dx.doi.org/10.1016/j. tourman.2008.02.024 
Swarbrooke, J. (2002). Sustainable tourism management. Oxon: CABI Publishing.

Taylor, M. (2000). Life, Land and Power, Contesting Development in Northern Botswana (Doctoral dissertation). University of Edinburgh.

Tosun, C. (2006). Expected nature of community participation in tourism development. Tourism Management, 27, 493-504. http://dx.doi.org/10.1016/j. tourman.2004.12.004

Tozser, A. (2010). Competitive tourism destination: Developing a new model of tourism competitiveness (Unpublished Doctoral thesis) at University of Miskolc, Faculty of Economic.

Trukhachev, A. (2015). Methodology for evaluating the rural tourism potentials: A tool to ensure sustainable development of rural settlements. Sustainability, 7, 30523070. http://dx.doi.org/10.3390/su7033052

Tsonis, J. L., Cheuk, S., Ing, G. P., \& Razli, I. A. (2009). An examination of the challenges faced in economic socio-cultural and environmental aspects of transport development and tourism in Malaysia. European Journal of Social Sciences, 11(4), 522-534.

Vengesayi, S. (2003). A conceptual model of tourism destination competitiveness and attractiveness. ANZMAC Conference Proceedings Adelaide.

Warren, C. (2013). Encouraging rural tourism to embrace bush fire risk management through business and visitor improvement strategies. International Centre for Responsible Tourism - Australia.

Weladji, R. B., Stein, R. M., \& Vedeld, P. (2003). Stakeholder Attitudes Towards Wildlife Policy and the Bonoe

Wildlife Conservation Area, North Cameroon. Environmental Conservation, 30(4), 334343. http://dx.doi.org/10.1017/S0376892903000353

Wilde, S. J., \& Cox, C. (2008). Linking destination competitiveness and destination development: Findings from a mature Australian tourism destination. Proceedings of the Travel and Tourism Research Association (TTRA) European Chapter Conference - Competition in Tourism: Business and Destination Perspectives, Helsinki, Finland, 467-478.

Williams, K. J. H., \& Cary, J. (2002). Landscape preferences, ecological quality, and biodiversity protection. Environment and Behavior, 34(2), 257-274. http://dx.doi. org/10.1177/0013916502034002006

World Tourism Organization. (1994) Global tourism forecasts to the Year 2000 and Beyond. Madrid: WTO.

World Travel and Tourism Council (WTTC), (2015). Economic Impact of Travel \& Tourism: 2015 Annual Update Summary. Report. Available at https://www.wttc. org/-/media/files/reports/economic\%20impact\%20research/regional\%202015/ world2015.pdf

Yoon, Y. (1998). Determinants of urban residents perceived impacts: A study of Williamsburg and Virginia Beach areas (Unpublished master thesis). Virginia Polytechnic Institute and State University, Blacksburg. 
Yoon, Y. (2002). Development of a structural model for tourism destination competitiveness from stakeholders' perspectives. Dissertation submitted to the Faculty of the Virginia Polytechnic Institute and State University in partial fulfillment of the requirement for the degree of Doctor of Philosophy in Hospitality and Tourism Management.

Yoon, Y., Gursoy, D., \& Chen, J. (2000). Validating a tourism development theory with structural equation modelling. Tourism Management, 22(4), 363-372. http://dx.doi.org/10.1016/S0261-5177(00)00062-5

$\mathrm{Yu}, \mathrm{A}$. (2014). Study on the development of county tourism. International Conference on Education, Language, Art and Intercultural Communication (ICELAIC 2014), 673-676. http://dx.doi.org/10.2991/icelaic-14.2014.172

Yu, C. P., Chancellor, H. C., \& Cole, S. T. (2011). Examining the effects of tourism impacts on resident quality of life: Evidence from rural Midwestern communities in USA. International Journal of Tourism Sciences, 11(2), 161-186. http://dx.doi.org/10.1 080/15980634.2011.11434643

Zeinali, B., \& Jafarpour, M. (2015). Does visitors' demographics, status, length-of-stay, and travel party affect loyalty indicators? A case of visitors to El-Golu Park, Iran. European Journal of Hospitality and Tourism Research, 3(1), 24-40.

Zhang, H., \& Lei, S. L. (2012). A structural model of residents' intention to participate in ecotourism, the Case of a wetland community. Tourism Management, 33, 916925. http://dx.doi.org/10.1016/j.tourman.2011.09.012

Zoto, S., Qirici, E., \& Polena, E. (2013). Agrotourism - A sustainable development for rural area of Korca. European Academic Research, 1(2), 209-223. 